\title{
OXYGEN TENSION IN TESTES OF NORMAL AND CRYPTORCHID RATS
}

\author{
E. D. MASSIE, W. R. GOMES AND N. L. VANDEMARK \\ Animal Reproduction Teaching and Research Center, The Ohio State University, \\ Columbus, Ohio 43210, U.S.A.
}

(Received 22nd February 1969)

Investigations by Moore (1924) were among the first to show degeneration of seminiferous elements of the mammalian testes during cryptorchidism. Since that time, a number of experiments have demonstrated that biochemical and metabolic changes occur in the cryptorchid testis, including changes in respiration (Tepperman, Tepperman \& Dick, 1949), glucose metabolism (Free, Vera Cruz, Johnson \& Gomes, 1968), lipid levels (Fleeger, Bishop, Gomes \& VanDemark, 1968) and gas tensions (Cross \& Silver, 1962). Alteration in blood gas tensions has been associated with testicular degeneration (Free \& VanDemark, 1968; Matteo \& Nahas, 1963; Waites \& Setchell, 1964) suggesting that a relationship may exist between cryptorchidism, gas tensions in the testis and tubular damage. The present study was undertaken to determine the effects of short-term cryptorchidism on oxygen tension in the rat testis.

Mature male Wistar rats were randomly assigned to four experimental groups: (1) unoperated controls, (2) 1-day cryptorchids, (3) 2-day cryptorchids, and (4) 4-day cryptorchids. Groups 2 to 4 contained both unilaterally and bilaterally cryptorchid rats.

Artificial cryptorchidism was produced as described earlier (Fleeger et al., 1968).

In vivo testicular oxygen measurements were made with a $1-\mathrm{mm}$ oxygen electrode attached to a physiological gas analyser (Model 160, Beckman Instruments Co.). The electrode was calibrated with known gas mixtures and accuracy was verified between each tissue measurement. For tissue measurement, a small incision was made in the scrotum or abdomen of an anaesthetized rat and an 18-ga. Riley needle with a stylette in the bore was inserted through the opening into the testis. The stylette was removed and replaced with the oxygen electrode. The electrode was allowed to stabilize and readings were taken every $15 \mathrm{sec}$ for $5 \mathrm{~min}$.

As shown in Table 1, oxygen tension in abdominal testes was twice as high as the level in scrotal testes of control or unilaterally cryptorchid rats within 1 day after the production of artificial cryptorchidism $(P<0.01)$ and remained at this doubled level throughout the 4-day experimental period $(P<0.01)$. Furthermore, no difference existed in oxygen tension between unilaterally and 
bilaterally cryptorchid testes, so these two groups were combined for presentation (Table 1).

Contradictory evidence exists as to the effect of elevated temperature on oxygen tension in the testis. Waites \& Setchell (1964) found that local heating increased in vivo oxygen uptake by the testis and suggested that oxygen became limiting, causing testicular degeneration. However, Cross \& Silver (1962) found that local heating of the scrotum caused a 10 to $40 \%$ increase in in vivo oxygen tension. Their control values for rabbit (11.6) and ram (11.4) testes were similar to the oxygen tension value found for control rat testes $(10.56)$ in the present study. The similarity of these values and the consistent readings found both within and among control rats in the present study suggests that tissue damage caused by the probe did not appreciably affect local oxygen tension.

TABLE 1

EFFECT OF GRYPTORGHIDISM ON IN VIVO OXYGEN TENSION IN RAT TESTES

\begin{tabular}{l|c|c|c}
\hline & $\begin{array}{c}\text { Days of } \\
\text { cryptorchidism }\end{array}$ & No. of testes & $\begin{array}{c}\text { Oxygen tension } \\
(\text { mm Hg } \pm \text { S.E. })\end{array}$ \\
\cline { 1 - 2 } Control & 0 & 40 & $10 \cdot 56 \pm 0 \cdot 45$ \\
Scrotal* & 1 & 18 & $9 \cdot 59 \pm 0 \cdot 60$ \\
& 2 & 14 & $10 \cdot 10 \pm 1 \cdot 36$ \\
Abdominal $\dagger$ & 1 & 24 & $10 \cdot 95 \pm 0 \cdot 66$ \\
& 2 & 26 & $19 \cdot 40 \pm 1 \cdot 26 \ddagger$ \\
& 4 & 24 & $20 \cdot 13 \pm 1 \cdot 81 \ddagger$ \\
& $18.93 \pm 0 \cdot 87 \ddagger$ \\
\hline
\end{tabular}

* Scrotal testes of unilaterally cryptorchid rats.

+ Abdominal testes of unilaterally and bilaterally cryptorchid rats.

$\ddagger$ Significantly different $(P<0.01)$ from control and scrotal testes.

Whether the increased oxygen tension in the testes of cryptorchid animals is the cause or effect of testicular degeneration, is open to question. Exposure of rats to an atmosphere of 95 to $98 \%$ oxygen results in rapid degeneration of testicular tissue (Matteo \& Nahas, 1963), suggesting that the elevated oxygen tension caused by cryptorchidism may contribute to testicular degeneration.

The reason for elevated oxygen tension in cryptorchid testes remains unknown. Cross \& Silver (1962) reported that heating the testis caused vasodilatation, but Setchell, Waites \& Thorburn (1965) were unable to confirm a consistent increase in testicular blood flow due to heating of the scrotum. Free \& VanDemark (1968) concluded that the increase in testicular oxygen tension during scrotal warming in the ram was accounted for by the physical effect of increased temperature on fluid gas tensions. According to their calculations, the $33 \%$ increase found in oxygen tension of spermatic venous blood could be attributed to the difference in scrotal and abdominal temperatures. Thus, it is probable that temperature alone accounts for part of the increased oxygen tension found in abdominal testes, but it seems unlikely that this could entirely account for the twofold increase found in the present study. 
The assistance of W. A. Applebaum is gratefully acknowledged in the collection of experimental data. This study was supported by USPHS Grant No. 9 R01 HD-03535.

\section{REFERENCES}

CRoss, B. A. \& Silver, I. A. (1962) Neurovascular control of oxygen tension in the testis and epididymis. 7. Reprod. Fert. 3, 377.

Fleeger, J. L., Bishop, J. P., Gomes, W. R. \& VanDemark, N. L. (1968) Testicular lipids. I. Effect of unilateral cryptorchidism on lipid classes. F. Reprod. Fert. 15, 1.

FREe, M. J. \& VANDEMark, N. L. (1968) Gas tensions in spermatic and peripheral blood of rams with normal and heat-treated testes. Am. F. Physiol. 214, 863.

Free, M. J., Vera Gruz, N. C., Johnson, A. D. \& Gomes, W. R. (1968) Metabolism of glucose-1-14C and glucose- $6-{ }^{14} \mathrm{C}$ by testis tissue from cryptorchid and testosterone propionate treated rabbits. Endocrinology, 82, 183.

Matteo, R. S. \& NAHAs, G. G. (1963) Sodium bicarbonate: increase in survival rate of rats inhaling oxygen. Science, $\mathcal{N} . X .141,719$.

Moore, C. R. (1924) Properties of the gonads as controllers of somatic and physical characteristics. IV. Testicular reactions in experimental cryptorchidism. Am. 7. Anat. 34, 269.

Setchell, B. P., Wartes, G. M. H. \& Thorburn, G. D. (1965) Blood flow in the testis of the conscious ram measured with krypton 85 . Circulation Res. 18, 755.

Tepperman, J., Tepperman, H. M. \& Dick, H. J. (1949) A study of the metabolism of rat testis in vitro. Endocrinology, 45, 491.

Waites, G. M. H. \& Setchell, B. P. (1964) Effect of local heating on blood flow and metabolism in the testis of the conscious ram. F. Reprod. Fert. 8, 339. 